\title{
Influence of different compacting methods on concrete compressive strength
}

\author{
Ronaldo Alves de Medeiros-Junior ${ }^{1}$, Maryangela Geimba de Lima ${ }^{2}$, \\ Alessandro Oliveira ${ }^{3}$
}

\author{
${ }^{1}$ Department of Civil Construction - Federal University of Parana (UFPR), Curitiba, Paraná, Brazil \\ ${ }^{2}$ Department of Civil Engineering - Technological Institute of Aeronautics (ITA), Sao Jose dos Campos, São paulo, Bra- \\ zil \\ ${ }^{3}$ Department of Civil Engineering - Odebrecht Transport/RioGaleao, Rio de Janeiro, Rio de Janeiro, Brazil \\ e-mail: ronaldodemedeirosjr@yahoo.com.br, magdlima@gmail.com, asoliveira@ riogaleao.com
}

\begin{abstract}
Adequate compacting is an important stage contributing for the durability and final quality of concrete structures. The two main ways of compacting concrete are: manual and mechanical (immersion vibrator). This paper has the goal of verifying the influence of those two compacting methods on the compressive strength of concrete from long term data. In order to do that, cylindrical test specimens of a same concrete were molded with different compacting methods and the compressive strength was investigated at 1, 3, 7, 14, 21, 28, $63,91,180,365$ and 730 days. Concrete used was casted in plant. Manual compacting was performed using a metallic and cylindrical rod. Mechanical compacting was performed using a rigid immersion vibrator driven by an electric motor. This study confirmed greater compressive strength in test specimens compacted with immersion vibrator, when compared with results in manually compacted test specimens. However, the novelty of this article is that variance analysis test demonstrated that only from 63 days the difference between compressive strengths is significant. Long term data also made it possible to generate a trend equation with good coefficient of determination for estimating the difference between compressive strengths for the two compacting methods investigated over time.
\end{abstract}

Keywords: Concrete, materials technology, compressive strength, durability, long term data.

\section{INTRODUCTION}

The concrete technology and manufacture control is important for detecting common problems during the execution of a construction and to avoid the premature degradation of concrete structures. The compacting of fresh concrete is an important stage in materials technology for reducing the amount of voids filled with trapped air and producing a more dense structure and, therefore, more resistant and less susceptible to the penetration of aggressive agents [1,2].

The adequate compacting of concrete contributes for the final quality and durability of those structures. Compacting is a commonly used method to make concrete flowable and to remove the excessive entrapped air. Two methods are mainly used in construction: mechanical and manual.

In the mechanical method, a vibration is introduced during concrete casting to ensure proper concrete consolidation. Generally, using vibration for compaction is the standard practice both for cast in place concrete and for precast concrete $[3,4]$. The manual compacting method is widely used in molding test specimens on the construction that are latter sent to laboratory in order to evaluate the quality of the concrete.

AL-KHAJA [5] verified the influence of the compression level of concrete over the penetration of chlorides in samples with ordinary Portland cement and sulphate-resisting cement. The used samples of concrete were cylindrical ( $\phi 15 \mathrm{~cm}$ x $30 \mathrm{~cm}$ of length). Some concrete cylinder mixes were consolidated during half of the time of conventional compacting, which defined two levels of compacting: $50 \%$ and $100 \%$ of full consolidation. Full consolidation was defined as the removal of entrapped air and appearance of a thin film of the cement paste on the surface of the concrete $[5,6]$. The results have shown that chloride ingress was the lowest in both conventional and sulphate-resisting concrete mixes made by $100 \%$ consolidation when compared with those made by $50 \%$ consolidation. An increase by about 1.23 times in chloride content (\% weight of cement) was observed. 
DATE et al. [3] detected that the productivity of concrete with vibration consolidation increases as the sand percentage and the content of fly ash also increase. There are a few techniques that can be used for monitoring the transmission process of the vibration effort for fresh concrete during compacting. In practice, there is no monitoring of the exact point where the vibrator was inserted or by how much time there was vibration in each point. Therefore, the quality of the compacting procedure is many times subjected only to the interpretation of the operator [4].

Therefore, producing a dense concrete without segregation with a vibrator tool requires an experienced vibrator operator. Inexperienced vibrator operators tend to over-consolidate or under-consolidate concrete. Thus, GONG et al. [4] discuss that the vibration step is a common source of problems in concrete construction; under-vibration may cause excessive entrapped air, cold joints, and subsidence cracking, for example; and over-vibration may cause segregation, form deflection, form damage, and an excess of paste/mortar at the surface.

It is also important to highlight that today is common the use of self-compacting concrete (SCC), contributing to eliminate a large portion of problems resulting from a failed compacting procedure. SCC is a type of concrete that does not require an external effort of compacting. After casting, SCC compacts under its own weight due to its excellent deformability, combined with enough cohesive characteristics to avoid problems of segregation or bleeding. The use of SCC also contributes to reduce construction time [7].

In dealing with conventional concrete, as discussed, the compacting stage of fresh concrete is important and may influence properties of the fresh and hardened concrete. Inside this context, compressive strength test is widely used in engineering for construction control and verification of concrete design. The standard NBR 12655 [8], for instance, establishes as criterion of acceptance control of concrete the tests of compressive strength and consistency (slump test).

The test of compressive strength performed in test specimens is normally used as a parameter for the final control of the concrete casting on the structure. This is also one of the most popular tests, sometimes performed wrongly, and its results are considered as the absolute truth, without complementary studies.

One of this paper discussions is the fact the Brazilian standards for compressive strength testing [9] allows using the manual or mechanical procedures for molding the test specimens. However, according to what is discussed in literature $[3,4,7]$, each one of the methods has its own characteristics; in order to verify if those characteristics interfere with the results of compressive strength testing, this paper has the objective of investigating the influence of the two main compacting methods (manual and mechanical) over this parameter of concrete, by means of monitoring the compressive strength of tests specimens during a period of 2 years.

\section{MATERIALS AND METHODS}

\subsection{Materials}

Cylindrical test specimens of $\phi 10 \mathrm{~cm}$ x $20 \mathrm{~cm}$ of length were molded, according to the standard NBR 5738 [10]. The molds used were metallic ones, prepared according procedure specified by the mentioned standard.

Concrete used was dosed in plant. Table 1 shows the characteristics of the concrete. A generally conventional mix concrete that is used widely for commercial construction was requested.

Portland cement of blast furnace and resistant to sulfate - CP III RS [11] - was used as binding agent. The fine aggregate used was natural sand and artificial stone powder (basaltic); the coarse aggregate was gravel basaltic. Table 2 shows the physical characterization of aggregates. The tests were performed according to NBR 7211 [12], NBR NM 45 [13], NBR NM 52 [14], NBR NM 53 [15] and NBR NM 248 [16] standards. Water used for concrete dosage was also analyzed (Table 3) according to NBR 15900 [17] and results show that the sample is within the general and specific requirements for waters to be used in mortar and cement concrete.

Table 1: Concrete mix.

\begin{tabular}{l|l|l|l|l}
\hline CEMENT & NATURAL FINE & ARTIFICIAL FINE & COARSE & WATER \\
\hline
\end{tabular}




\begin{tabular}{l|l|l|l|l}
\hline $\left.\mathbf{( k g} / \mathbf{m}^{\mathbf{3}}\right)$ & AGGREGATE $\left(\mathbf{k g} / \mathbf{m}^{\mathbf{3}}\right)$ & AGGREGATE $\left(\mathbf{k g} / \mathbf{m}^{\mathbf{3}}\right)$ & AGGREGATE $\left(\mathbf{k g} / \mathbf{m}^{\mathbf{3}}\right)$ & $\left(\mathbf{1} / \mathbf{m}^{\mathbf{3}}\right)$ \\
\hline 351 & 529 & 277 & 1003 & 191 \\
\hline
\end{tabular}

Table 2: Aggregates characterization.

\begin{tabular}{l|l|l|l|l}
\hline AGGREGATE & $\begin{array}{l}\text { SPECIFIC MASS } \\
\left(\mathbf{k g} / \mathbf{d m}^{\mathbf{3}}\right)\end{array}$ & $\begin{array}{l}\text { UNIT MASS } \\
\left(\mathbf{k g} / \mathbf{d m}^{\mathbf{3}}\right)\end{array}$ & $\begin{array}{l}\text { MAXIMUM DIMENSION } \\
(\mathbf{m m})\end{array}$ & FINENESS \\
\hline Natural fine aggregate & 2.62 & 1.40 & 2.40 & 2.45 \\
Artificial fine aggregate & 2.70 & 1.55 & 4.80 & 2.65 \\
Coarse aggregate & 2.70 & 1.49 & 25.00 & 7.19 \\
\hline
\end{tabular}

Table 3: Water characterization.

\begin{tabular}{l|l|l|l}
\hline PARAMETERS & $\begin{array}{l}\text { RESULT IN 100 ML OF } \\
\text { WATER DILUTED AT 10\% }\end{array}$ & $\begin{array}{l}\text { RESULT IN 100ML OF THE } \\
\text { SAMPLE, 10\% FILTERED }\end{array}$ & $\begin{array}{l}\text { MAXIMUM ALLOWED } \\
\text { VALUE }\end{array}$ \\
\hline Iron (mg/l) & 0.03 & 0.03 & 1 \\
Silica (mg/l) & 6.10 & 6.00 & $\mathrm{NE}$ \\
Manganese (mg/l) & 0.08 & 0.10 & $\mathrm{NE}$ \\
Nitrite (mg/l) & 0.10 & 0.07 & $\mathrm{NE}$ \\
Nitrate (mg/l) & 1.00 & 1.00 & $\mathrm{NE}$ \\
Sulfate (mg/l) & 19.00 & 17.00 & 300 \\
pH (laboratory) & 7.10 & 7.10 & $6.00-9.50$ \\
\hline
\end{tabular}

According to NBR NM 67 [18], the slump test was performed for receiving the concrete. This test was performed after collecting the sample, as required by NBR NM 33 [19]. A slump of $60 \mathrm{~mm}$ was identified for the used concrete. According to NBR 5738 [10], this slump may be compacted by manual or mechanical procedure. With this result, the procedure of molding the test specimens started.

\subsection{Methods}

\subsubsection{Compacting methods of the test specimens}

Two compacting procedures described by current standards were selected to fulfill the objective of this paper; the used procedures were the manual and mechanical compacting.

Manual compacting was performed as prescribed by NBR 5738 [10], using metallic and cylindrical rod. Those rods have flat surface and dimensions of $\phi 1.6 \mathrm{~cm}$ and $65 \mathrm{~cm}$ of length, one of the extremities is semi spherical, with diameter equal to the one of the rod. The filling of molds was performed in two layers of approximately the same volume, compacted with 12 strokes each one. Then, in each specimen was performed the leveling of the surface, using a metallic ruler.

Mechanical compacting was also performed according to NBR 5738 [10]; for this, a rigid immersion vibrator driven by an electric motor was used. In the specific case of this study (test specimens $\phi 10 \mathrm{~cm} \times 20$ $\mathrm{cm}$ of length), a hose of $\phi 2.5 \mathrm{~cm}$ was used. The vibrator was introduced in a single layer of the test specimens, remaining during approximately 3 seconds, until the surface of the concrete had a relatively flat surface without air bubbles on it. In sequence, the test specimens were leveled, using metallic ruler. Test specimens were unmolded after 24 hours of molding and remained in moist chamber (relative humidity $>95 \%$ ) until the date of testing.

\subsubsection{Compressive strength of concrete}


In this paper the compressive strength test was performed at the following ages: 24 hours, 3, 7, 14, 21, 28, 63, 91, 180, 360 and 730 days; thus, until the sample completed 2 years of age. In order to do that, a total of 44 test specimens were molded, two of them for each study condition (manual of mechanical compacting) for each age.

Compressive strength was determined according to standard NBR 5739 [9]; test specimens were broken in a universal press for tests (model HD-200T), under constant load speed, on each age previewed.

\section{RESULTS AND DISCUSSION}

Individual results of compressive strength of all test specimens are presented in Figure 1. Figure 2 shows the evolution of compressive strength as a function of age for each condition of compacting. Standard deviation estimated inside the test was 1.14 and $1.25 \mathrm{MPa}$, for manual and mechanical compacting conditions, respectively.

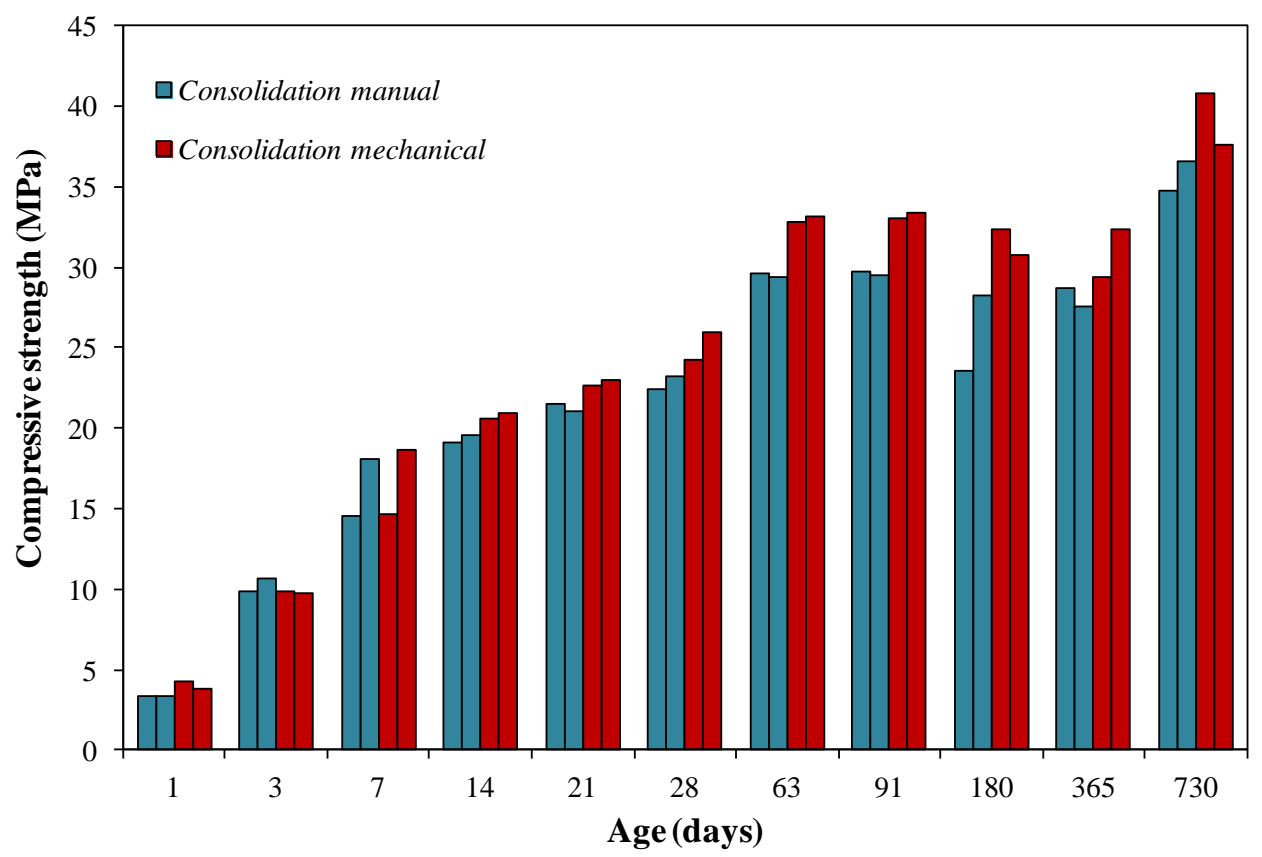

Figure 1: Individual compressive strength (MPa) of each test specimen.

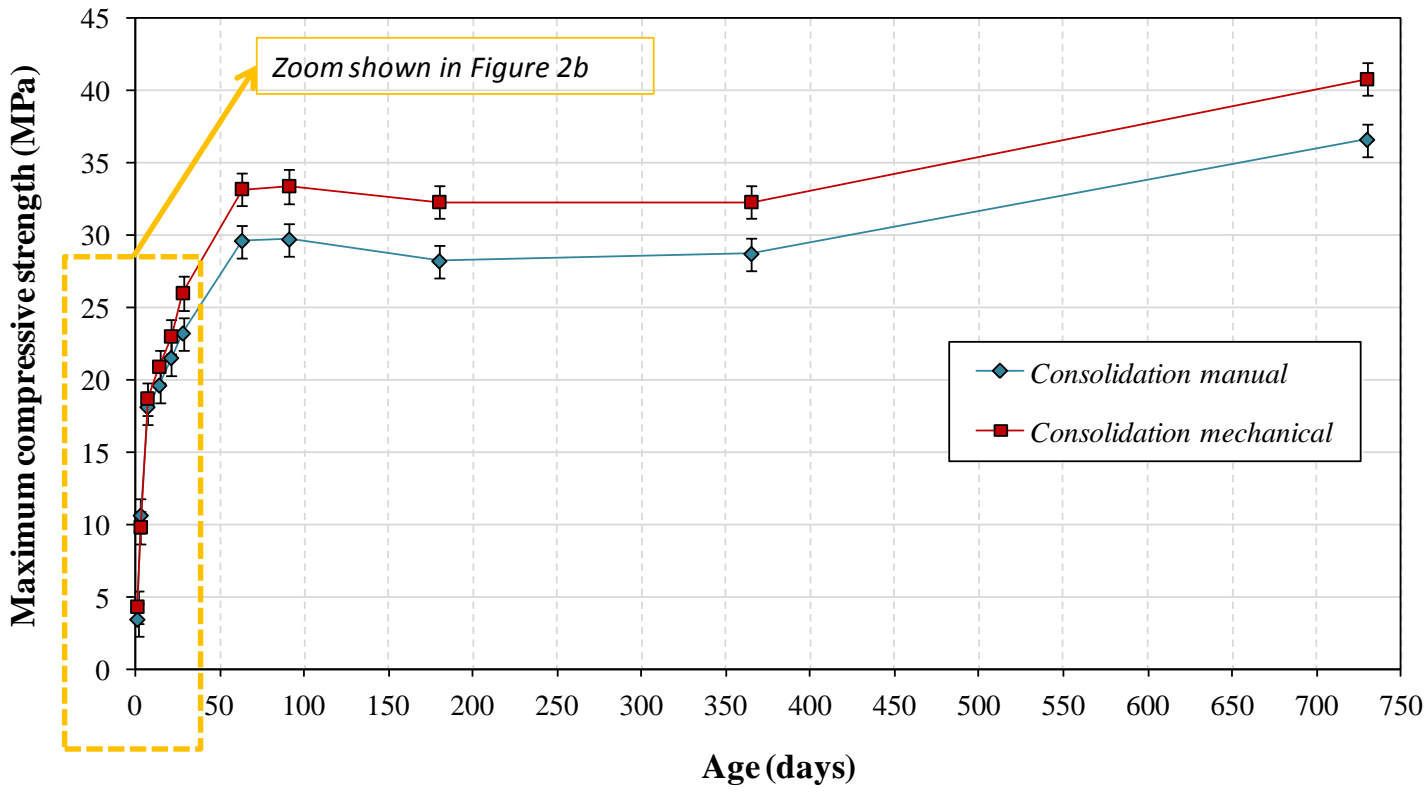




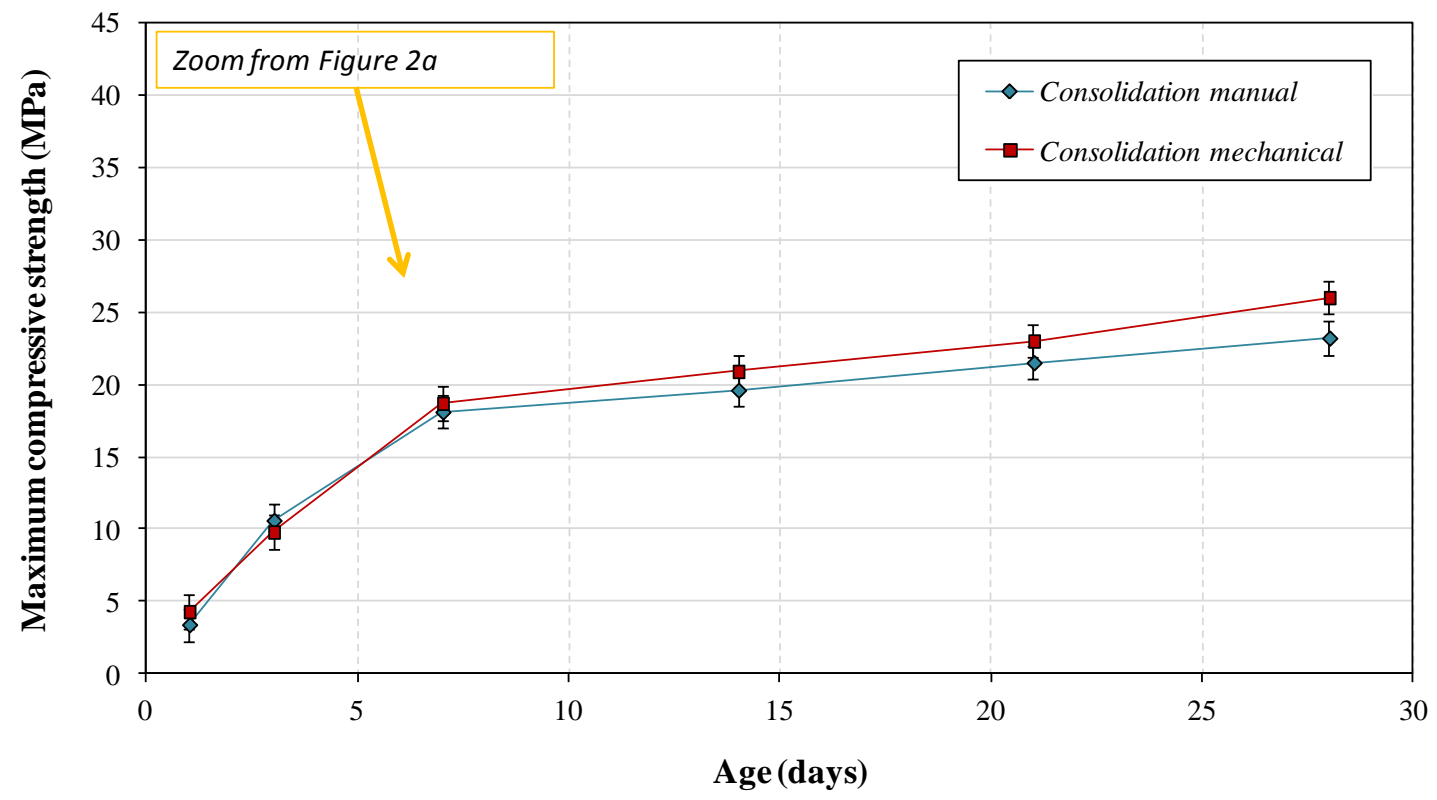

Figure 2: (a) Evolution of compressive strength (MPa) as a function of age for the different compacting conditions; (b) Zoom from Figure $2 \mathrm{a}$ - ages from 1 to 28 days.

According to Figure 2, in general, concrete with mechanical compacting (vibration) had compressive strength superior than concrete with manual compacting. This means that mechanical vibration tends to produce better compaction in the concrete. This produces a denser pore structure leading to increase in mechanical resistance.

Another point observed is that the difference between resistances according to the compacting method used grows with the concrete age. Observing Figure 2, until 28 days of age, there is no large visual difference between methods. However, after 28 days, this difference gradually becomes greater, reaching the value of $11.5 \%$ for the age of 2 years. This value seems to be significant, considering that, according to data from this paper, it represents a difference of 4.2 MPa, therefore over the standard deviation determined for the testing (=1.14 and 1.25 $\mathrm{MPa}$, as already reported).

One-way analysis of variance, also known as ANOVA, was performed in order to verify if the difference of resistances between both compacting methods is really significant. One-way ANOVA produces an analysis for a quantitative dependent variable affected by a single factor (independent variable). This analysis is commonly used to verify the significance of differences between two or more media.

In the present study, the null hypothesis for ANOVA test states that data of compressive strength of the compared method show the same behavior and are not different from each other. In contrast, the alternative hypothesis states that these measures are different and thus did not have the same kind of behavior. The significance level threshold was $\alpha=0.05$. Thus, if $\alpha$ is less than 0.05 , the null hypothesis should be rejected. The results of ANOVA test for combinations of manual and mechanical consolidation are given in Table 4 .

Table 4: Results of ANOVA test.

\begin{tabular}{l|l|l}
\hline AGE ANALYZED (DAYS) & $\boldsymbol{\alpha}$ & NULL HYPOTHESIS \\
\hline $1-730$ & 0.456 & accepted \\
$28-730$ & 0.059 & accepted \\
$63-730$ & 0.025 & rejected \\
\hline
\end{tabular}

According to Table 4, when the whole testing period is analyzed together, in other words, results of the compacting test from the first day until 2 years, the significance level of ANOVA test is greater than 0.05. This indicates that the null hypothesis cannot be rejected, meaning there is no statistically significant difference between the two measurements. When the analyzed age is from 28 days until 2 years, significance level falls drastically from 0.456 to 0.059 ; however it stays slight above 0.05 . However, analyzing the differences 
between resistances from 63 days, the result of ANOVA test did not confirm the null hypothesis. This means that those measurements are different and do not have the same behavior.

Therefore, variance analysis allows concluding that from 63 days, the manual and mechanical compacting methods produce significant differences in the compressive strengths of concrete. Although Figure 1 shows visually that manual compacting compressive strength is slightly higher than mechanical at 3 and 7 days, statistical test shows that these results (manual and mechanical at 3 and 7 days) are statistically not different.

Figure 3 shows the trend line for the variation amplitude as a function of concrete age. For that, variation amplitude is defined as the differences between the resistance of mechanically compacted concrete less resistance of manually compacted concrete.

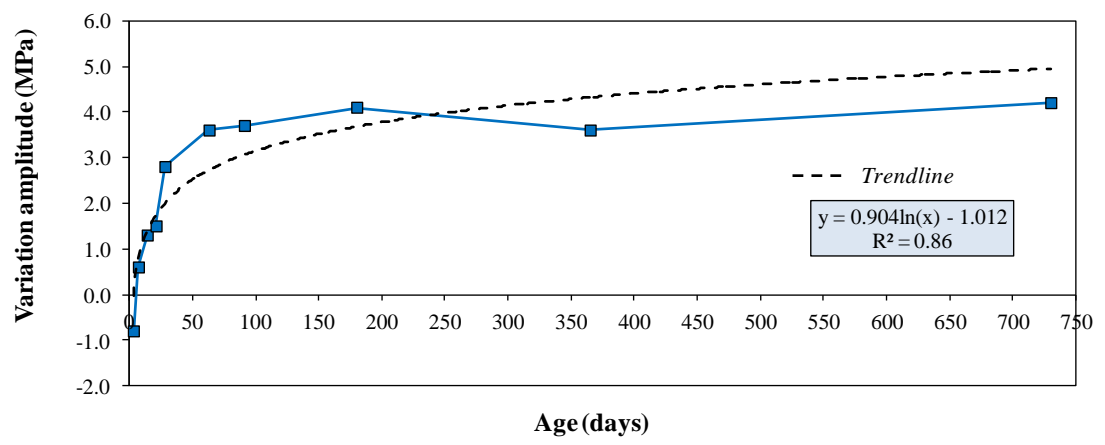

Figure 3: Evolution of difference between compressive strengths obtained by mechanical and manual compacting as a function of age.

According to Figure 3, the best fit found for the data was logarithmic (coefficient of determination = 0.86). Equation 1 is proposed for determination the difference between compressive strengths according to the compacting method used.

$$
y=0.904 \ln (t)-1.012
$$

Where: $y$ represents the difference of compressive strengths (mechanical less manual, in $\mathrm{MPa}$ ), and $t$ the concrete age (days).

Application of Equation 1 must yet be investigated for longer duration data (over 2 years) and for different concrete mixtures. However, it is an interesting tool to be used under the conditions assumed in this paper.

In a practical application, following, a trend of variation between resistances during the service life of a concrete structure is estimated. In order to do that, a service life of 50 years (value commonly used for current constructions) is adopted and Equation 1 is applied for this situation. Figure 4 shows the results.

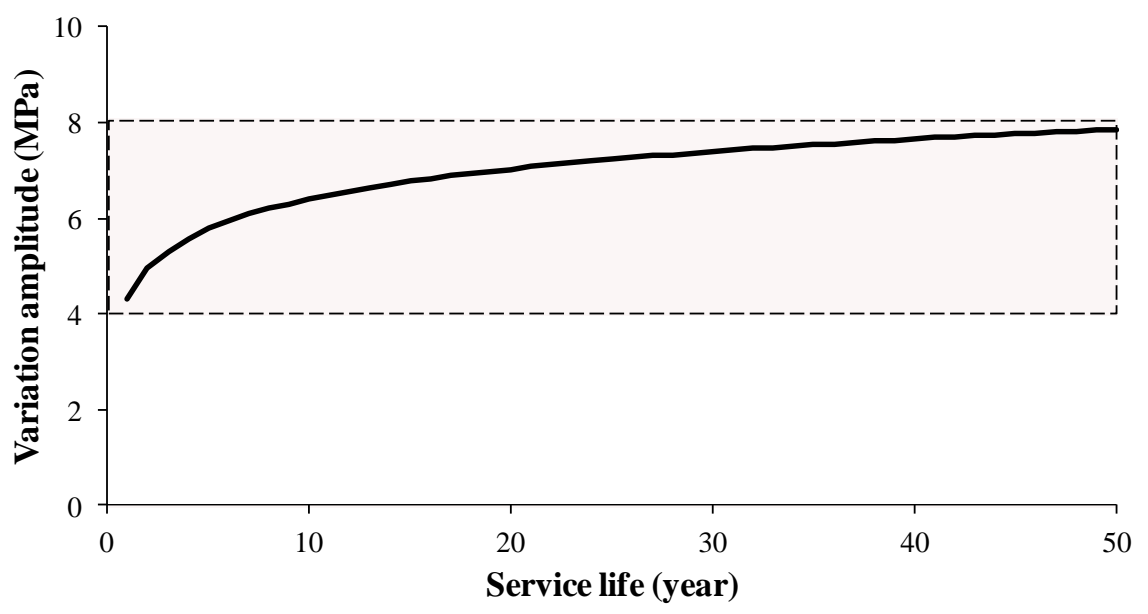


Figure 4: Estimated behavior for the difference of resistances between compacting methods during a 50 years' service life - data estimated according to conditions assumed on this paper.

According to Figure 4, a range of resistance variation between 4 and $8 \mathrm{MPa}$ is expected during the structure service life. This means that the resistance of concrete mechanically compacted may be about 8 MPa over the resistance of the same concrete manually compacted.

Thus, although the difference in resistance between the compression methods for early ages (28 days) is not expressive, to advanced age can be quite high. Since much of the resistance investigations are carried out up to 28 days, this type of analysis is only allowed for long-term studies. Thus, this article showed that the resistance behavior due to different methods can be modified from 63 days.

\section{CONCLUSIONS}

Results of this paper show that there are significant differences between compressive strength of concrete mechanically and manually compacted from 63 days of age. A difference of $11.5 \%$ at 2 years of age between the two compacting methods studied was verified, representing about 4.2 MPa. This article proves gains of resistance on the mechanically compacted test specimens, with immersion vibrator, when compared to results of test specimens manually compacted.

In practical (real cases of construction), this means: considering only the compacting condition, resistances greater than the ones obtained on the test specimens are expected on the structure for ages up to 63 days, since normally the concrete of the construction is mechanically compacted and the test specimens are manually compacted. However, all other factors involved, especially cure conditions, should also be considered.

This paper highlights the important of cares regarding the compacting method of test specimens during the technological control of the construction concrete, recommending that compacting test specimens should always be performed in the same way. This means that, when there is technological control performed by the responsible for the construction and by the responsible from the concrete provider (in the plant), the compacting methods must be equal, at the risk of having distinct values, mainly for ages over 63 days, as demonstrated in this study. Therefore, the preparation of test specimens must be done properly, avoiding that false results may cause problems both for the owner of the construction as well as for the professionals responsible by its execution and control.

With the data and conditions assumed in this paper, a trend equation with a good coefficient of determination was generated; it is estimated that during the service life of a concrete structure (50 years), the resistance of concrete mechanically compacted may be between 4-8 MPa higher than the one of the same concrete manually compacted.

\section{ACKNOWLEDGEMENTS}

Authors would like to acknowledge the Aeronautics Institute of Technology (ITA), the Vale do Paraiba University (UNIVAP), Odebrecht Transport/RioGaleão and CAPES.

\section{BIBLIOGRAPHY}

[1] MEDEIROS-JUNIOR, R.A., LIMA, M.G., et al., "Investigação da resistência à compressão e da resistividade elétrica de concretos com diferentes tipos de cimento", Revista Alconpat, v. 4, n. 2, pp. 116-132, Abr. 2014.

[2] BALESTRA, C.E.T, LIMA, M.G., SILVA, A.R., et al., "Corrosion degree effect on nominal and effective strengths of naturally corroded reinforcement", Journal of Materials in Civil Engineering, v. 28, n.10, pp. 1-9, May. 2016.

[3] DATE, S., GORYOZONO, Y., HASHIMOTO, S., "Study on consolidation of concrete with vibration", Physics Procedia, v. 25, n. n/a, pp. 325-332, Apr. 2012.

[4] GONG, J., YU, Y., KRISHNAMOORTHY, R., et al., "Real-time tracking of concrete vibration effort for intelligent concrete consolidation”, Automation Construction, v. 54, n. n/a, pp. 12-24, Jun. 2015.

[5] AL-KHAJA, W.A., "Influence of temperature, cement type and level of concrete consolidation on chloride ingress in conventional and high-strength concretes", Construction and Building Materials, v. 11, n. 1, pp. 9-13, Feb. 1997. 
[6] MORRIS, P.H., DUX, P.F., “Analytical solutions for bleeding of concrete due to consolidation”, Cement and Concrete Research, v. 40, n. 10, pp. 1531-1540, Oct. 2010.

[7] SHI, C., WU, Z., LV, K., et al., "A review on mixture design methods for self-compacting concrete", Construction and Building Materials, v. 84, n. n/a, pp. 387-398, Jun. 2015.

[8] NBR 12655. Concreto de cimento Portland - Preparo, controle, recebimento e aceitação - Procedimento. Rio de Janeiro, ABNT - Associação Brasileira de Normas Técnicas, Brasil, 2015.

[9] NBR 5739. Concreto - Ensaio de compressão de corpos-de-prova cilíndricos - Método de ensaio. Rio de Janeiro, ABNT - Associação Brasileira de Normas Técnicas, Brasil, 2007.

[10] NBR 5738. Moldagem e cura de corpos-de-prova cilíndricos ou prismáticos de concreto. Rio de Janeiro, ABNT - Associação Brasileira de Normas Técnicas, Brasil, 2008.

[11] NBR 5735. Cimento Portland de alto forno. Rio de Janeiro, ABNT - Associação Brasileira de Normas Técnicas, Brasil, 1991.

[12] NBR 7211. Agregados para concreto - Especificação. Rio de Janeiro, ABNT - Associação Brasileira de Normas Técnicas, Brasil, 2009.

[13] NBR NM 45. Agregados - Determinação da massa unitária e do volume de vazios. Rio de Janeiro, ABNT - Associação Brasileira de Normas Técnicas, Brasil, 2006.

[14] NBR NM 52. Agregado miúdo - Determinação da massa específica e massa específica aparente. Rio de Janeiro, ABNT - Associação Brasileira de Normas Técnicas, Brasil, 2009.

[15] NBR NM 53. Agregado graúdo - Determinação da massa específica, massa específica aparente e absorção de água. Rio de Janeiro, ABNT - Associação Brasileira de Normas Técnicas, Brasil, 2009.

[16] NBR NM 248. Agregados - Determinação da composição granulométrica. Rio de Janeiro, ABNT - Associação Brasileira de Normas Técnicas, Brasil, 2003.

[17] NBR 15900. Água para amassamento do concreto - Parte 1-11. Rio de Janeiro, ABNT - Associação Brasileira de Normas Técnicas, Brasil, 2009.

[18] NBR NM 67. Concreto - determinação da consistência pelo abatimento do tronco de cone. Rio de Janeiro, ABNT - Associação Brasileira de Normas Técnicas, Brasil, 1998.

[19] NBR NM 33. Concreto - amostragem de concreto fresco. Rio de Janeiro, ABNT - Associação Brasileira de Normas Técnicas, Brasil, 1998. 